\title{
Serotonin-prefrontal cortical circuitry in anxiety and depression phenotypes: pivotal role of pre- and post-synaptic 5-HT1A receptor expression
}

\author{
Paul R. Albert ${ }^{1 *}$, Faranak Vahid-Ansari ${ }^{1,2}$ and Christine Luckhart ${ }^{1,2}$ \\ ${ }^{1}$ Neuroscience, Ottawa Hospital Research Institute, University of Ottawa, Ottawa, ON, Canada \\ ${ }^{2}$ Department of Cellular and Molecular Medicine, University of Ottawa, Ottawa ON, Canada
}

Edited by:

Zoe R. Donaldson, Columbia

University, USA

Reviewed by:

Eduardo David Leonardo, Columbia

University, USA

Orna Issler, Weizmann Institute of

Science, Israel

Alvaro L. Garcia-Garcia, Columbia

Univeristy, USA

\section{${ }^{*}$ Correspondence:}

Paul R. Albert, Neuroscience,

Ottawa Hospital Research Institute,

University of Ottawa, 451 Smyth

Road, Ottawa, ON K1H-8M5,

Canada

e-mail:palbert@uottawa.ca
Decreased serotonergic activity has been implicated in anxiety and major depression, and antidepressants directly or indirectly increase the long-term activity of the serotonin system. A key component of serotonin circuitry is the 5-HT1A autoreceptor, which functions as the major somatodendritic autoreceptor to negatively regulate the "gain" of the serotonin system. In addition, 5-HT1A heteroreceptors are abundantly expressed post-synaptically in the prefrontal cortex (PFC), amygdala, and hippocampus to mediate serotonin actions on fear, anxiety, stress, and cognition. Importantly, in the PFC 5-HT1A heteroreceptors are expressed on at least two antagonist neuronal populations: excitatory pyramidal neurons and inhibitory interneurons. Rodent models implicate the 5-HT1A receptor in anxiety- and depression-like phenotypes with distinct roles for pre-and post-synaptic 5-HT1A receptors. In this review, we present a model of serotonin-PFC circuitry that integrates evidence from mouse genetic models of anxiety and depression involving knockout, suppression, over-expression, or mutation of genes of the serotonin system including 5-HT1A receptors. The model postulates that behavioral phenotype shifts as serotonin activity increases from none (depressed/aggressive not anxious) to low (anxious/depressed) to high (anxious, not depressed). We identify a set of conserved transcription factors including Deaf1, Freud-1/CC2D1A, Freud-2/CC2D1B and glucocorticoid receptors that may confer deleterious regional changes in 5-HT1A receptors in depression, and how future treatments could target these mechanisms. Further studies to specifically test the roles and regulation of pyramidal vs. interneuronal populations of 5-HT receptors are needed better understand the role of serotonin in anxiety and depression and to devise more effective targeted therapeutic approaches.

Keywords: anxiety, depression, interneurons, pyramidal neurons, prefrontal cortex, raphe nuclei, serotonin receptors, transcription factors

\section{INTRODUCTION}

\section{DEPRESSION AND ANXIETY: ROLES OF SEROTONIN AND PREFRONTAL CORTEX (PFC)}

Depression and anxiety are complex and heterogeneous disorders with a global disease burden that is steadily increasing and has currently surpassed most other major diseases (Whiteford et al., 2013). Their onset occurs during childhood to adolescence persisting throughout lifetime. Depression and anxiety are often comorbid and display a relapsing and remitting course that becomes resistant to pharmacologic treatment (Gorwood, 2004; Trivedi et al., 2006; Krishnan and Nestler, 2008; Rush et al., 2009). Depression is complex in part because the diagnostic criteria do not distinguish between different behavioral facets of depression, hence very different subsets of depressed patients are "lumped" together (Krishnan and Nestler, 2008). Nevertheless, twin studies demonstrate a clear genetic component, and a large number of studies have implicated gene $\mathrm{x}$ environment interactions as a key determinant of depression primates (Caspi et al., 2010). Prominently adverse, stressful environment in early post-natal or adolescent life increases the likelihood of depression and the strength of association of genetic variant with depression.

Several lines of evidence implicate decreased serotonergic activity in anxiety and major depression, but its importance in the etiology and severity of these disorders remains unclear (Millan, 2004; Wong et al., 2005; Jans et al., 2007; aan het Rot et al., 2009; Booij et al., 2010). Acute tryptophan depletion studies support a role for decreased serotonin in depression, or at least in relapse of recovered depressed patients (Barnes and Sharp, 1999; Young and Leyton, 2002; Jans et al., 2007; Lanfumey et al., 2008; aan het Rot et al., 2009). Imaging and post-mortem studies indicate altered activity of discrete regions within the prefrontal cortex (PFC) and their atrophy are associated with depression (Rajkowska et al., 2005; Ressler and Mayberg, 2007). Genetic polymorphisms in serotonin genes [e.g., 5-HT transporter (5-HTT), 5-HT1A receptor] have been associated with depression, but these associations are weak and not always reproducible, suggesting that serotonin may be a predisposing factor rather than a cause of depression or anxiety (Karg et al., 2011; Kishi et al., 2013). The mainstay 
of pharmacological treatment targets serotonin and/or other monoamine systems, but these approaches have very modest treatment effects and initial monotherapy with serotonin-specific reuptake inhibitor (SSRI) is ineffective to achieve sustained remission in a majority of patients (Trivedi et al., 2006; Rush et al., 2009). More recently the finding that ketamine can induce rapid antidepressant effect coincident with remodeling and spine development in the PFC suggest a key role for the PFC in depression and its treatment (Aan Het Rot et al., 2012; Duman and Li, 2012). Deep brain stimulation of discrete sites within the PFC has elicited remarkable improvement in depression symptoms in some depressed patients, supporting the key role for hypo/hyperactivity of different regions of the PFC in depression (Ressler and Mayberg, 2007; Holtzheimer and Mayberg, 2011). Interestingly, the beneficial effects of deep brain stimulation in animal models of depression depend on 5-HT, indicating a primary role of the 5-HT-PFC circuitry in effective treatment of depression (Hamani and Nobrega, 2012). In this review, we focus on the role of preand post-synaptic 5-HT1A receptors in regulating the activity of this circuitry, and on the behavioral outcomes of modifying this circuitry.

\section{THE SEROTONIN SYSTEM: ROLES OF PRE- AND POST-SYNAPTIC RECEPTORS}

The brain serotonin system consists of a small group of neurons located in the raphe nuclei of the midbrain that are unique since they express the rate-limiting enzyme for serotonin synthesis, tryptophan hydroxylase-2 (TPH2), the brain specific isoform Walther et al., 2003; Lenicov et al., 2007). The differentiation of neuronal progenitors to express serotonergic markers like TPH2 is driven by the transcription factor Pet-1, which directly activates the TPH2 gene (Hendricks et al., 2003). 5-HT neurons of the rostral raphe nuclei, including the dorsal and median raphe nuclei, project widely throughout the brain to innervate key brain regions involved in anxiety and depression. Activation of serotonin neurons induces release of serotonin at target neurons and within the raphe via collateral branches (Kocsis et al., 2006; Bang et al., 2012), which is rapidly removed by the 5-HTT, the target of SSRI antidepressants. Serotonin released in the raphe activates the 5-HT1A autoreceptor, which negatively regulates the firing of serotonin system. Release of serotonin at target neurons activates 5-HT heteroreceptors including the 5-HT1A heteroreceptor which is abundantly expressed in the hippocampus, septum, amygdala, and PFC (Albert et al., 1990) where it mediates serotonin actions on fear, anxiety, stress, and cognitive function (Barnes and Sharp, 1999; Gross and Hen, 2004; Savitz et al., 2009; Meltzer et al., 2012; Donaldson et al., 2013; GarciaGarcia et al., 2013). Since the 5-HT1A receptor is coupled to inhibitory Gi/Go proteins (Barnes and Sharp, 1999; Albert and Tiberi, 2001), it inhibits the firing and activity of target neurons (Celada et al., 2004; Puig and Gulledge, 2011; Llado-Pelfort et al., 2012). The other major 5-HT receptor (particularly in cortex) is the Gq-coupled 5-HT2A receptor, which mediates excitatory actions of serotonin on target neurons (Celada et al., 2004; Puig and Gulledge, 2011; Llado-Pelfort et al., 2012). Thus in terms of neural circuitry, the 5-HT1A receptor is inhibitory, while the 5-HT2A receptor is stimulatory. However, these receptors can also couple to protein kinase pathways in a cell-specific manner that may stimulate gene transcription and indirectly enhance neuronal function in the long term (Kushwaha and Albert, 2005; Mogha et al., 2012). For the purpose of clarity, we focus on the 5-HT1A as the major inhibitory receptor and 5-HT2A as the major stimulatory receptor in $\mathrm{PFC}$, although there are complementary roles for other stimulatory 5-HT receptors in PFC, such as 5-HT3, 5-HT4, and 5-HT7 receptors (Beique et al., 2004).

\section{TARGETED GENETIC MODIFICATION OF THE SEROTONIN SYSTEM AND BEHAVIOR TRANSGENIC AND KNOCKOUT APPROACHES}

Several mouse models have targeted the 5-HT1A receptor gene or genes involved in determining 5-HT levels or 5-HT neurotransmission in the brain (Table 1) (Jacobsen et al., 2012a; Lesch et al., 2012; Donaldson et al., 2013). More recently these studies have included conditional and inducible knockout or suppression approaches summarized in Box 1. Gene knockout approaches result in irreversible loss of gene function, while inducible suppression or expression approaches allow for reversible expression. Inducible expression of CRE (for inducible knockout) has mainly been done use the CRE-ERT2 construct, which is activated by tamoxifen treatment. Inducible suppression has been done using a doxycycline-suppressible repressor construct (Tanaka et al., 2010). By the use of tissue-specific promoters, these approaches can target specifically serotonin neurons (using Pet-1 or TPH2 promoters) or forebrain regions (usually CAMKII $\alpha$ promoter). The Pet-1/TPH2 promoters have been used to drive expression of CRE recombinase in all midbrain serotonin neurons from the initiation of their differentiation, with $\mathrm{TPH} 2$ driving somewhat stronger expression. On the other hand, the CAMKII promoter drives expression starting at the early post-natal period and is widely expressed in glutamatergic pyramidal neurons of the forebrain but excluded from interneurons (Xu et al., 2000; Chen et al., 2010). Together, these approaches provide both region- and cell type-specific gene targeting that can be induced or reversed at different developmental times.

\section{RODENT BEHAVIORAL READOUTS OF ANXIETY, DEPRESSION AND AGGRESSION}

These rodent genetic models have been examined for 5-HT neurotransmission and for anxiety, depression, and aggressionrelated behaviors using a standard set of assays (Table 1). Anxiety behavior has been typically assayed using elevated plus maze (Lister, 1987), light-dark box, open field tests (Bouwknecht et al., 2004; Crawley, 2008), which measure acute anxiety-like behavior. In some cases novelty-suppressed feeding assay, which has greater face validity since it responds to chronic and not acute SSRI treatment (Santarelli et al., 2003). Depression-like behavior has mainly been studied using acute tests like tail suspension (Liu and Gershenfeld, 2003) or forced swim tests (Porsolt et al., 1977; Castagne et al., 2009). These tests measure acute depression or behavioral despair in an inescapable stress and are used to identify antidepressant compounds. In a few cases, the sucrose preference test has been done to assess anhedonia (Krishnan et al., 2008). Aggression has been evaluated using the resident-intruder test, and social interaction with animal vs. object or novel animal was 
Table 1 | 5-HT genetic models summary.

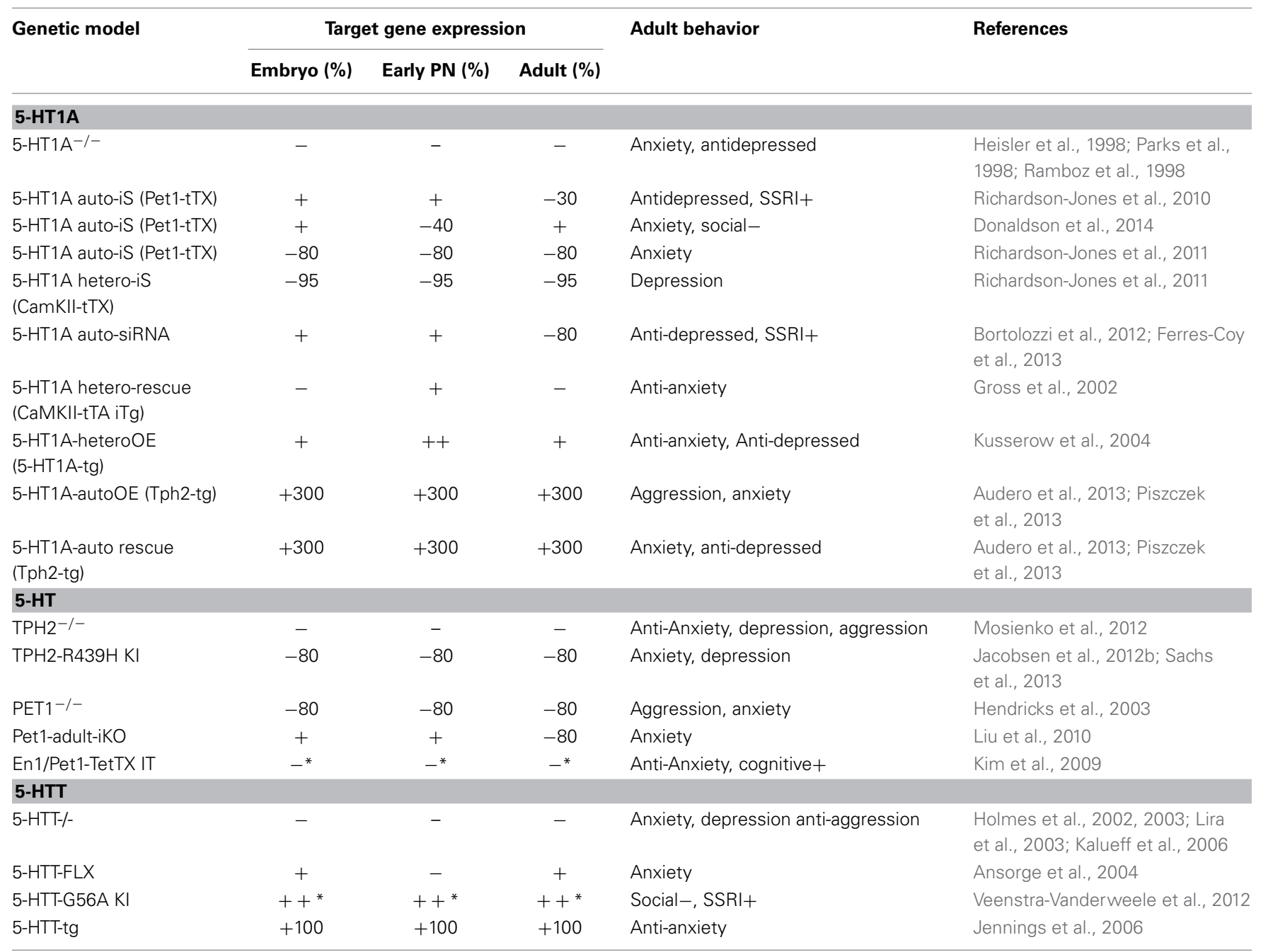

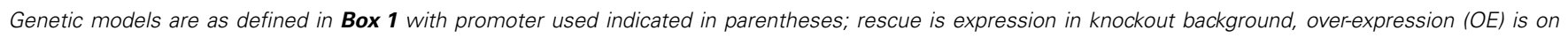
wild-type background; auto, autoreceptor-specific; hetero, heteroreceptor-specific. The effect of the indicated genetic model on target gene expression (-, none; +,

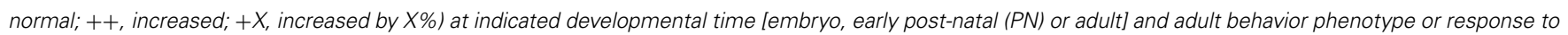
SSRI are indicated. *loss of 5-HT release; enhanced activity 5-HTT mutant.

quantified. These tests assess limited phenotypes compared to the more complex phenotypes of anxiety disorders or major depression in humans. Thus the circuitry models presented below are in the context of these assays of anxiety- or depression-like behavior that may correspond to discrete endophenotypes of anxiety disorder or depression in humans.

\section{SEROTONIN-PFC CIRCUITRY IN ANXIETY AND DEPRESSION RODENT MODELS SEROTONIN-PFC CIRCUITRY MODEL IN THE ANXIETY PHENOTYPE}

Comparing different genetic models, the effects of modifications of the serotonin system on anxiety behavior may often appear paradoxical or in conflict (Table 1), but can be in part accounted for by the model of 5-HT-PFC circuitry presented in Figure 1. This model takes into account that there are two major sub-populations of heteroreceptors in the PFC: 5-HT1A receptors on pyramidal glutamatergic neurons that inhibit their activity; and 5-HT1A receptors on interneurons that reduce inhibition to enhance pyramidal neuron activity (AmargosBosch et al., 2004; Santana et al., 2004). Immunostaining has identified 5-HT1A receptors on human pyramidal axon initial segment and parvalbumin positive chandelier cells in layer II/III (DeFelipe et al., 2001); pyramidal neurons in layer 2 tree shrew (Palchaudhuri and Flugge, 2005). 5-HT1A receptor RNA is present in $80 \%$ of glutamatergic neurons in external layers II and upper III, and in around 50\% in layer VI (de Almeida and Mengod, 2008). Electrophysiological studies show presence of 5-HT1A receptors in pyramidal and interneurons, the latter mediating inhibition of pyramidal activity (AmargosBosch et al., 2004; Santana et al., 2004). In cortical neurons, 5-HT1A receptor activation inhibits NMDA currents (Yuen et al., 2008), and reduces CAMKII-induced AMPA phosphorylation (Cai et al., 2002), resulting in an inhibition of neuronal activity. 


\section{Box 1 | List of genetic manipulations. \\ Genetic models presented in Table 1 are summarized below \\ Transgenic (Tg): Promoter-gene; Promoter dependent expression of gene; non-reversible \\ Knockout (KO, ${ }^{-/-}$): Gene disrupted; ubiquitous; lifetime; non-reversible \\ Conditional KO (cKO): flx-gene-flx X Promoter-CRE: Gene disrupted in CRE-expressing cells only; promoter-dependent onset; non- reversible \\ Conditional induction: flx-STOP-flx-gene X Promoter-CRE: Gene induced in CRE-expressing cells; promoter-dependent onset; non-} reversible

Inducible Knockout (iKO): flx-gene-flx X Promoter-CRE-ERT2: Gene disrupted upon treatment (tamoxifen) in CRE-expressing cells only; age-specific; non-reversible

Inducible Transgenic (iTg): TetO-KI-gene X Promoter-tTA; Promoter- and doxycycline regulated expression of gene; tissue-specific; promoter-dependent onset; reversible with doxycycline

Inducible Suppression (iS): TetO-KI-genel X Promoter-tetR-KRAB; Promoter- and doxycycline regulated suppression of gene; tissuespecific; promoter-dependent onset; reversible with doxycycline treatment

Knockin (KI): Recombination of mutant gene for w.t.; normal gene expression pattern retained; non-reversible

Intersectional Transgenic (IT): flx-STOP-flx-flp-STOP2-flp-gene x promoter1-CRE x promoter2-FLP: gene expression dependent on inter section of promoters 1 and 2; promoter-dependent onset; non-reversible

siRNA suppression: siRNA depletes target gene; can be targeted to 5-HT neurons by fusion to SSRI; reversible within few days.

Critical aspects of the serotonin circuit model in anxiety (Figure 1) are:

- The hypothesized greater sensitivity of 5-HT1A receptors on interneurons compared to relatively lower sensitivity of 5-HT1A receptors on glutamatergic pyramidal neurons that mediate the anxiety phenotype;

- the greater activity of 5-HT2A vs. 5-HT1A receptors located on pyramidal neurons during the early post-natal period compared to adult (Beique et al., 2004) that once activated 5-HT2A receptors antagonize 5-HT1A signaling and stimulate glutamatergic output (Celada et al., 2004; Puig and Gulledge, 2011; Llado-Pelfort et al., 2012);

- increasing activity of this pyramidal projection increases anxiety.

The evidence for a role of 5-HT1A receptors on interneurons is mainly from systemic agonist (8-OHDPAT) administration studies in anaesthetized rats: DPAT reduces interneuron firing and increases pyramidal cell firing (blocked by GABAzine) (LladoPelfort et al., 2012). Pharmacological depletion of endogenous $5-\mathrm{HT}$ in PFC to 5\% of normal, reduced pyramidal firing from about $2 \mathrm{~Hz}$ to $1 \mathrm{~Hz}$, suggesting that interneuronal 5-HT1A inhibition may play the predominate role in pyramidal activity under basal anaesthetized conditions. However, the role of pyramidal vs. interneuron 5-HT1A receptors in pyramidal firing activity needs to be tested in awake behaving conditions using specific blockade or knockout of these subpopulations of 5-HT1A receptors. There is also evidence for a developmental switch in 5-HT-induced responses in pyramidal neurons (Beique et al., 2004). Although 5-HT2A receptors have 10 -fold lower affinity for 5-HT, in early post-natal development 5-HT excites PFC pyramidal cells via activation of highly expressed 5-HT2A (and 5-HT7) receptors, while 5-HT1A receptors are weakly coupled. With maturation, 5-HT1A receptor inhibition predominates over 5-HT2A function (which becomes desensitized) as rats mature from early post-natal period to adulthood.

In the anxiety model (Figure 1), under normal conditions both 5-HT1A heteroreceptors on pyramidal and interneurons are engaged, resulting in a balance between 5-HT1A-mediated inhibition and dys-inhibition of pyramidal anxiety output neurons. In mice with complete or nearly complete loss of 5-HT (Figure 1, No 5-HT; Table 1, TPH2 or TPH1/2 double knockout), 5-HT1A inhibition of both pyramidal and interneurons is predicted to be inactive and tonic interneuronal inhibition of pyramidal neurons to predominate, thereby reducing anxiety. Similarly, in mice expressing tetanus toxin in 5-HT neurons there is a similar outcome of reduced anxiety since release of 5 -HT is prevented, thus mimicking a lack of 5-HT. In models where $5-\mathrm{HT}$ is reduced but not entirely eliminated (Figure 1, Low 5-HT; Table 1, Pet-1-/-, TPH-R439H knockin) the model predicts that high affinity 5 -HT1A receptors on interneurons are preferentially engaged compared to those on pyramidal cells, relieving GABA-mediated inhibition of pyramidal neurons in the anxiety circuit, resulting in over-activation by even mild stressors and an elevated anxiety phenotype (Holmes, 2008). Similarly, over-expression of 5-HT1A autoreceptors also reduces 5-HT activity leading to a hyperactive anxiety circuit by preferentially relieving inhibition of pyramidal neurons. On the other hand, global knockout of all 5-HT1A receptors would allow for hyper-activation of raphe neurons (due to absence of 5-HT1A autoreceptor) and activation of pyramidal 5-HT2A receptors that is not antagonized by pyramidal 5-HT1A receptors due to their homologous and heterologous (5-HT2A-mediated) desensitization, leading to increased anxiety. Pyramidal 5-HT2A receptors may also actively suppress interneuronal GABA-mediated inhibition via activation of protein kinase C (Bright and Smart, 2013). Consistent with a pro-anxiety role, mice lacking 5-HT2A receptors display reduced anxiety that is reversed by Emx1driven cortical re-expression of 5-HT2A receptors (Weisstaub 

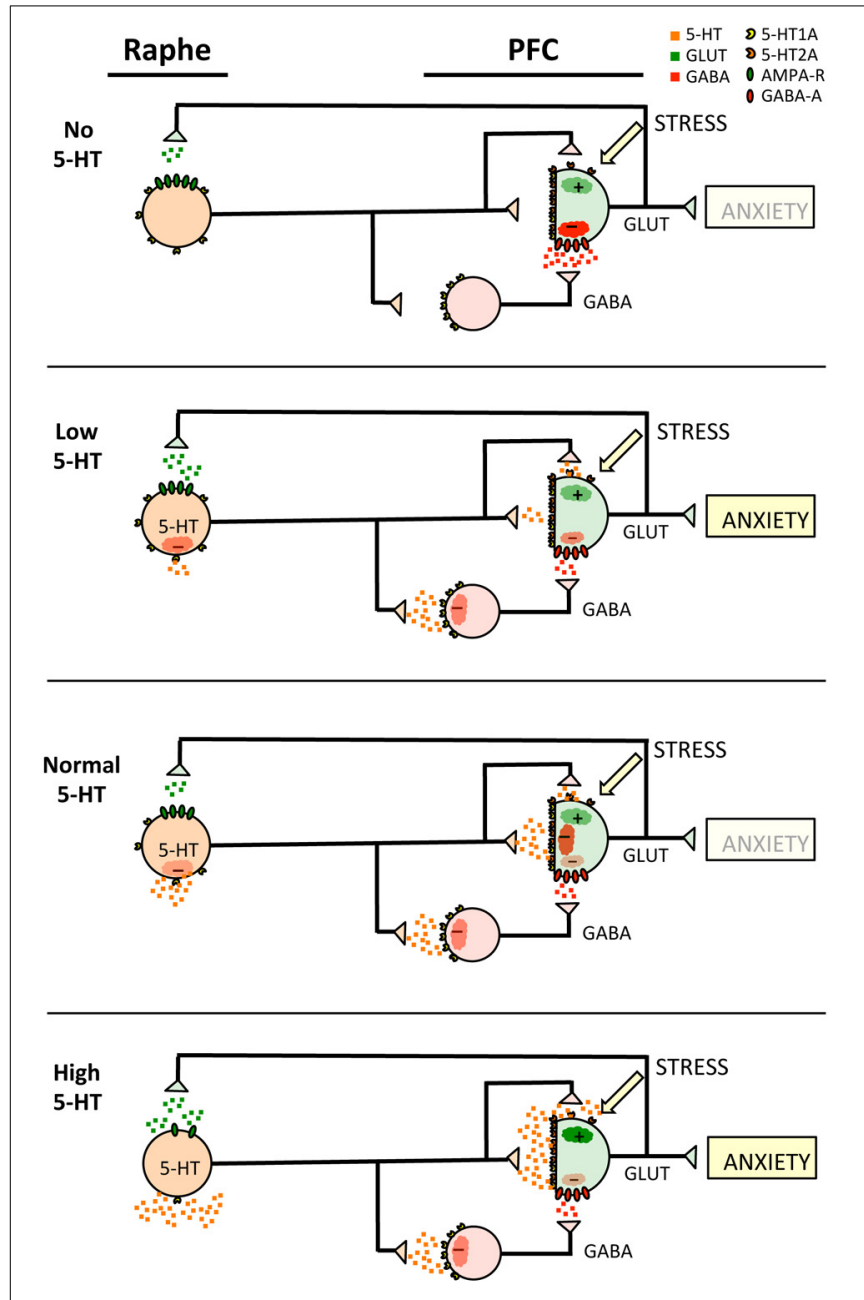

FIGURE 1 | Early post-natal 5-HT-PFC circuitry in anxiety models.

Shown are the components of the Raphe 5-HT-PFC circuit in animals during the early post-natal period with no, low, normal or high levels of 5-HT neurotransmission as indicated. Evidence from genetic mouse models (Table 1) supports the importance of alterations in early post-natal circuitry in generating the adult anxiety phenotype. The model shows 5-HT neurons (orange) projecting to prefrontal cortex GABAergic interneurons (red) and glutamatergic pyramidal neurons (green) with transmitter release illustrated as small squares of the same colors. Although 5-HT neurons are shown projecting separately to glutamatergic or GABAergic PFC neurons to illustrate the different activities of these pathways, the same 5-HT neuron may innervate both cells with different efficiency synapses or varicosities (Bang et al., 2012). The presence of 5-HT1A (yellow), 5-HT2A (orange) and GABA-A receptors (red) is shown, as well as the response in the target neurons (clouds), stimulatory (+) or inhibitory (-). The effect of chronic stress to stimulate pyramidal output is also indicated. It is postulated that 5-HT1A-mediated inhibition in the early post-natal period and perhaps adult is greater in interneurons than pyramidal neurons and that increased pyramidal neuronal activity triggers the anxiety phenotype, especially during the early post-natal period.

et al., 2006). In addition, 5-HT2A receptor levels are increased in early life stress and confer vulnerability to PFC hyperactivation and anxiety (Benekareddy et al., 2010). Consistent with this model, blockade of 5-HT2A receptors reduces anxiety induced by post-natal SSRI, while post-natal blockade of 5-HT1A receptors induces anxiety (Sarkar et al., 2013). Oppositely, early post-natal CaMKII $\alpha$-driven rescue of 5-HT1A heteroreceptors on pyramidal neurons in the 5- $\mathrm{HT}_{1} \mathrm{~A}^{-/-}$background rescues the anxiety phenotype (Gross et al., 2002). Early post-natal over-expression of the 5-HT1A receptor in wild-type background also reduced anxiety (Kusserow et al., 2004). On the other hand, CaMKII $\alpha$ driven promoter suppression of 5-HT1A receptors on pyramidal neurons (Richardson-Jones et al., 2011) may have had little effect on anxiety due to the maintained inhibition by GABAergic neurons. Thus, upon hyper-activation of the 5-HT system (High 5-HT, Figure 1), interneurons are predicted to be suppressed by interneuronal 5-HT1A activation while 5-HT2A receptors are predicted to respond to high 5-HT to activate pyramidal neurons and desensitize pyramidal 5-HT1A and GABA signaling via protein kinase C activation (Lembo and Albert, 1995; Wu et al., 2002), leading to a hyper-activated pyramidal activity and an anxiety phenotype.

The 5-HT1A receptor seems to play its major role in establishing the anxiety phenotype during the early post-natal period. For example, CaMKII $\alpha$-driven promoter rescue of 5-HT1A receptor expression in adult $5-\mathrm{HT}_{1} \mathrm{~A}^{-/-}$mice failed to restore normal anxiety (Gross et al., 2002). Similarly, suppression of 5-HT1A autoreceptor expression during the early post-natal period but not adulthood elicited anxiety phenotype (Richardson-Jones et al., 2010; Donaldson et al., 2014). This critical period for the anxiety phenotype is associated with a developmental increase in the activity of 5-HT1A receptors on pyramidal neurons during this period (Beique et al., 2004). Suppressing pyramidal 5-HT1A signaling by hyper-stimulating 5 -HT2A receptors or by partially reducing 5-HT activity leads to the hyper-activation of pyramidal neurons to drive the anxiety phenotype. Anxiety in the 5-HT1A knockout mouse appears to be resistant to the over-expression in adulthood of 5-HT1A receptors in pyramidal cells, suggesting that the predominance of 5-HT2A signaling prevents the inhibitory function of 5-HT1A receptors. Interestingly early life stress increases 5-HT1A RNA and 5-HT1A-induced potassium current in the PFC, which may be a protective adaptation that gradually diminishes with maturation to adulthood (Goodfellow et al., 2009); while 5-HT2A receptor signaling is also increased resulting in increased serotonin excitability of these neurons (Benekareddy et al., 2010).

\section{SEROTONIN-PFC CIRCUITRY MODEL IN THE DEPRESSION PHENOTYPE}

Evidence from human imaging studies suggests that different subpopulations of PFC neurons with different targets mediate anxiety vs. depression behavior (Ressler and Mayberg, 2007; Krishnan and Nestler, 2008; Savitz et al., 2009). In addition, early postnatal development appears to be more important in the anxiety phenotype (see above) compared to the depression phenotype. Due to these differences, the serotonin circuitry model for depression involves similar components but is slightly different from the anxiety model (Figure 2). First, opposite to anxiety, activation of the pyramidal neuron is associated with reduced depression and increased resilience. Second, we propose that the 5-HT2A receptor is weakly active in the mature pyramidal neurons controlling depression (Beique et al., 2004). Based on this the major serotonergic control over the pyramidal neuron is through the 

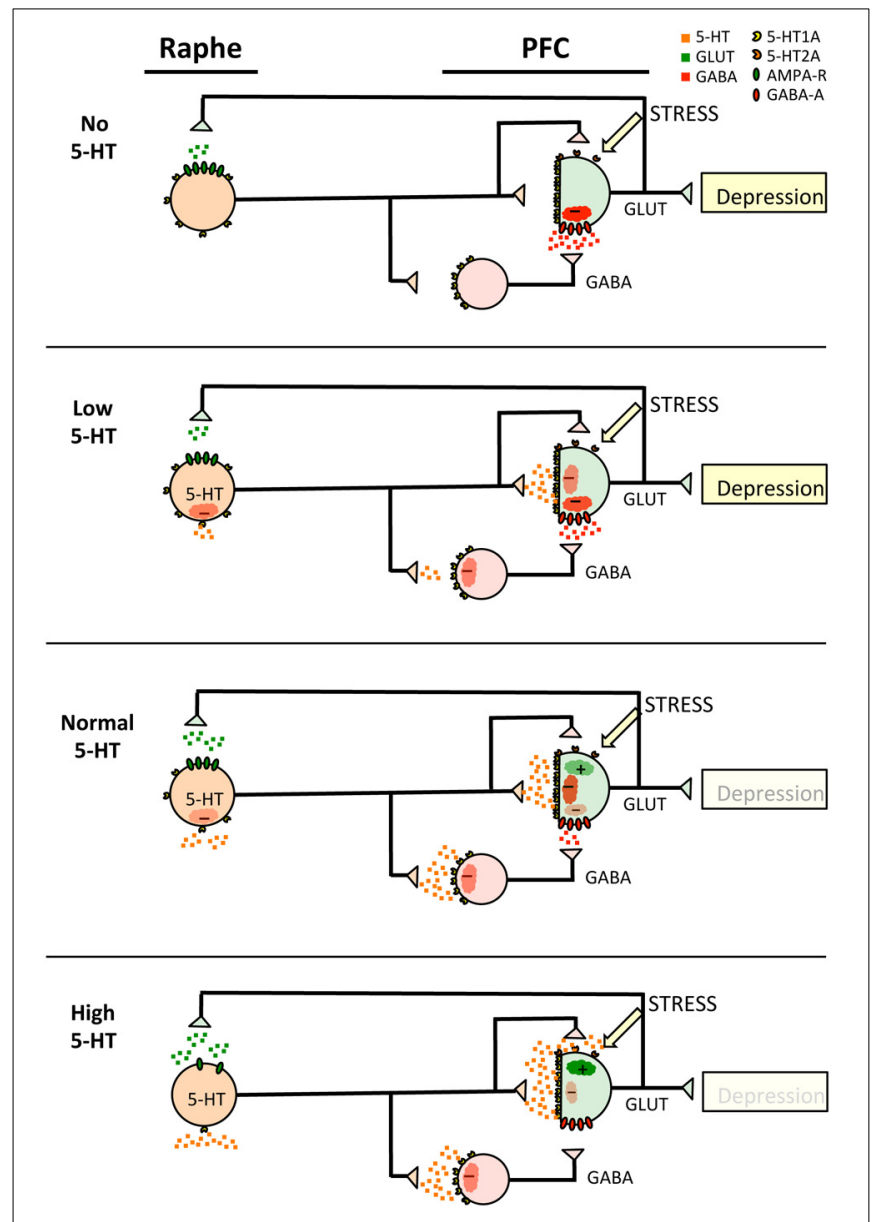

FIGURE 2 | Adult 5-HT-PFC circuitry in depression models. Shown are the components of the Raphe 5-HT-PFC circuit in adult animals with no, low, normal or high levels of 5-HT neurotransmission as indicated. The model shows 5-HT neurons (orange) projecting to prefrontal cortex GABAergic interneurons (red) and glutamatergic pyramidal neurons (green) with transmitter release illustrated as small squares of the same colors. The presence of 5-HT1A (yellow), 5-HT2A (orange), AMPA-glutamate (green) and GABA-A receptors (red) is shown, as well as the response in the target neurons (clouds), stimulatory (+) or inhibitory (-). The effect of stress to stimulate pyramidal output is also indicated. It is postulated that 5-HT1A-mediated inhibition in adulthood becomes predominant in pyramidal neurons compared to interneurons, and that reduced activity of target pyramidal neurons elicits depression during adulthood.

pyramidal 5-HT1A receptor that reduces activity, but is almost saturated at normal 5-HT levels; at high 5-HT levels, 5-HT2A or other excitatory receptors (5-HT4, 5-HT7) are recruited to activate the pyramidal neurons and inactivate 5-HT1A signaling (Hedlund et al., 2005; Lucas et al., 2007). Finally, in this model the interneuronal 5-HT1A receptor is weakly active at normal 5-HT, hence is a target of SSRI to enhance inhibition of the interneuron thus further activating the pyramidal neuron. This model fits with genetic models involving loss or increase in 5-HT levels, and also with models of inhibition of adult 5-HT1A autoreceptor levels. For example, the TPH2 $2^{-/-}$and TPH2-R439H mutant that reduce or eliminate 5-HT show depression phenotypes (Jacobsen et al., 2012b; Mosienko et al., 2012; Sachs et al., 2013). Oppositely suppression of 5-HT1A autoreceptors in adult to increase 5-HT activity reduces depression behavior (Richardson-Jones et al., 2010; Bortolozzi et al., 2012; Ferres-Coy et al., 2013) (Table 1). Reduction of 5-HT1A autoreceptors in adulthood is associated with accelerated and increased release of 5-HT at target areas and enhanced SSRI-mediated behavioral improvement in depression and anxiety (Richardson-Jones et al., 2010; Bortolozzi et al., 2012; Ferres-Coy et al., 2013). This is consistent with the negative feedback role of 5-HT1A autoreceptors in regulating serotonergic activity, and the need to down-regulate their expression for SSRI to exert antidepressant activity (Albert and Francois, 2010).

However, the lack of effect on depression of lifetime suppression or over-expression of 5-HT1A autoreceptors (RichardsonJones et al., 2011; Audero et al., 2013) is not accounted for in this model, suggesting that there may be early life adaptations to compensate for the over- or under-expression of 5-HT1A autoreceptors. Suppression of 5-HT1A heteroreceptors (using the CAMKII $\alpha$ promoter to target pyramidal neurons) would be predicted to increase pyramidal neuron firing and display an anxiety phenotype rather than depression according to the model proposed. Autoradiography of the hetero-receptor suppressed mouse brain shows almost complete loss of cortical 5-HT1A binding (Richardson-Jones et al., 2011), suggesting that in this model CAMKII $\alpha$ promoter is active in interneurons (as well as pyramidal cells), perhaps due to embryonic-initiated suppression. Reduced interneuron 5-HT1A receptors would enhance interneuron firing and inhibit pyramidal firing, leading to a depression phenotype similar to the low or no 5-HT condition according to the model (Figure 2). This result in Hetero-1A suppressed mice suggests that 5-HT2A excitation upon loss of 5-HT1A heteroreceptors is insufficient to drive the anxiety phenotype or prevent depression when the 5-HT1A autoreceptor is present.

Consistent with the above model for depression, there is evidence of a 50\% reduction in major depression of calbindin-positive interneurons (which are 5-HT1A+ by in situ hybridization de Almeida and Mengod, 2008) and not of parvalbumin-positive interneurons (which lack 5-HT1A RNA) (Rajkowska et al., 2007). In this case, serotonergic activation would not reduce inhibitory interneuron feedback upon pyramidal neurons, leading instead to a further inhibition of pyramidal neurons, which could account for treatment resistant depression.

An aggressive phenotype is revealed in knockout models that produce a strong reduction of 5-HT (e.g., TPH2 knockout), but does not appear in 5-HT1A models (Table 1). Thus other 5-HT receptor subtypes may be involved, such as the 5-HT1B receptor (Saudou et al., 1994). In humans, aggressive behavior is more strongly associated with reduced 5-HT metabolites in cerebrospinal fluid than is depression, and in combination with depression, is a risk factor for suicide (Asberg, 1997). The presence of aggressive or impulsive behavior with depression seen in the "no 5-HT" (or very low 5-HT) condition, is consistent with findings of reduced 5-HT synthesis in aggressive subjects (Booij et al., 2010), and may increase likelihood of suicide attempt (Mann, 2013).

\section{OPTOGENETIC STUDIES OF THE SEROTONIN-PFC CIRCUITRY IN DEPRESSION AND ANXIETY}

Optogenetic studies have provided important data for the formulation of serotonin-PFC circuitry models of anxiety and 
depression. For depression, specific optogenetic stimulation of rat PFC pyramidal neurons projecting to the raphe increased kicking frequency in the FST, indicating that these raphe-projecting pyramidal neurons drive the "antidepressed" response in this assay (Warden et al., 2012). These neurons are part of the long negative feedback system involving pyramidal 5-HT1A receptors that mediate inhibition of raphe activation by this projection (Figure 2). Oppositely, a different set of PFC neurons project to the lateral habenula to inhibit the kick response, inducing a "prodepressive" state. Thus, different populations of PFC neurons may project to induce pro- or anti-depressant phenotypes, but it is not known whether the 5-HT1A receptor is expressed in the lateral habenula projecting neurons as it is in those that project to raphe. If not, modulation of 5-HT1A receptor activity in PFC would target the antidepressant response in a specific way.

Other studies suggest a similar circuitry to that proposed for PFC may exist in the hippocampal CA1 region (Varga et al., 2009). Optogenetic stimulation of raphe projections inhibits CA1 pyramidal neurons via 5-HT1A receptors on these neurons; in addition, raphe projections innervate interneurons activating them via 5-HT3 receptors, but also inhibiting them via 5-HT1A receptors. Further studies are needed to examine the specific contribution of 5-HT neurons to these actions. These studies suggest that the serotonin circuitry model that we propose for the PFC may be replicated in part in other brain regions such as the hippocampus that mediate serotonin-regulated behavioral and cognitive actions.

\section{TRANSCRIPTIONAL MODIFIERS OF 5-HT1A RECEPTOR EXPRESSION IN ANXIETY AND DEPRESSION}

Given the role of altered serotonin regulation in these genetic models of mouse behavior, what insights can be made into more effective treatment of human depression and anxiety by targeting different populations of the 5-HT1A receptor? One approach may be to "reset" the transcriptional regulation of the 5-HT1A receptor gene (Albert, 2012). The 5-HT1A receptor gene is regulated by a number of identified transcription factors, some of which show cell-specificity. For example, PET-1 is required for 5-HT1A receptor expression specifically in serotonin neurons due to its exclusive expression in these neurons, although it is not required in adult neurons (Liu et al., 2010). Other transcription factors that may dynamically regulate 5 -HT1A receptors in the brain include Deaf1 and Freud-1/Freud-2 repressor proteins.

\section{THE 5-HT1A C(-1019)G POLYMORPHISM AND DEAF1}

The human 5-HT1A C(-1019)G polymorphism (rs6295) is located upstream of the basal promoter in a palindromic DNA element that is recognized at the $\mathrm{C}$-allele by transcription factors Deaf1 and Hes1/5 (Lemonde et al., 2003; Jacobsen et al., 2008). Hes1/5 expression in brain is restricted to early developmental neural progenitors and is switched off as they differentiate into mature neurons. Hesl mediates stronger repression than Hes5, and gene knockout of Hes 1 in mice results in premature embryonic over-expression of 5-HT1A receptors in the midbrain and hindbrain (Jacobsen et al., 2008). Deaf1 is expressed in the brain throughout development and in adulthood. Deaf1 represses 5-HT1A receptor expression in raphe cells (Lemonde et al., 2003), yet enhances its transcription in some non-serotonergic cells (Czesak et al., 2006). Importantly Deaf1 is strongly expressed in several regions that are enriched on 5-HT1A receptors, especially raphe nuclei, PFC and hippocampal CA1 pyramidal neurons (Lemonde et al., 2003; Szewczyk et al., 2009). In Deaf1-/- mice, a $50 \%$ upregulation of 5-HT1A autoreceptors was observed, with a $30 \%$ reduction in 5 -HT1A expression in PFC but no change in hippocampus, consistent with a neuron-specific regulation by Deaf1 (Czesak et al., 2012). Activation of Deaf1 could have beneficial effects: reducing 5-HT1A autoreceptor expression to enhance serotonergic activity while increasing 5-HT1A heteroreceptors in PFC. It is unclear however, whether 5-HT1A receptors on prefrontal pyramidal neurons, interneurons or both are affected by Deaf1. It is unclear whether Deaf1 is also expressed in interneurons. In septal SN-48 cells, which express 5-HT1A receptors and are GABAergic (Charest et al., 1993), Deafl enhances 5-HT1A receptor transcription (Czesak et al., 2006), suggesting that it may have enhancer activity on 5-HT1A receptors in interneurons but this remain to be addressed. Deaf1 is expressed in 5-HT1A+ pyramidal neurons of the human PFC, particularly lamina II/III (Szewczyk et al., 2009). In antidepressant-free female depressed subjects Deaf1 and 5-HT1A protein levels were decreased, consistent with reduced 5-HT1A-mediated inhibition of pyramidal neurons in depression that may be driven by reduced Deaf1 expression (Szewczyk et al., 2009). Interestingly, estrogen induces Deaf1 protein levels in cultured neuronal cells (Adeosun et al., 2012), which could underlie a more prominent role in female depression. Although activation of Deaf1 could be beneficial in treatment of anxiety and depression, Deaf1 may also have beneficial actions on the immune system including enhancing responses to peripheral tissue antigens and to viral antigens (Yip et al., 2009; Ordureau et al., 2013).

The 5-HT1A C(-1019)G polymorphism (rs6295) appears to alter 5-HT1A receptor expression in humans and is associated with major depression, suggesting a role for Deaf1 in human depression. In particular, this polymorphism has been associated with major depression (Lemonde et al., 2003; Kishi et al., 2013), bipolar depression (Kishi et al., 2013), completed suicide (Wasserman et al., 2006) (although not suicidal ideation or attempt) and anxiety disorders as well as reduced response to SSRI and antipsychotics that target 5-HT1A receptors (Le François et al., 2008; Newman-Tancredi and Albert, 2012). In one study, the strongest association was seen in patients with depression and comorbid anxiety (Molina et al., 2011). Adult stress, but not early life stress, in combination with the risk G-allele increases the association with increased stress reactivity, depression and suicide (Wasserman et al., 2006; Benedetti et al., 2011; Mekli et al., 2011; Lebe et al., 2013). However in a larger study of normal subjects no such associations were found (Chipman et al., 2010). PET imaging studies in non-medicated depressed subjects show that the GG genotype is associated increase 5-HT1A receptors in raphe, with little change in post-synaptic regions (Hesselgrave and Parsey, 2013). Others groups have reported decreases in postsynaptic 5-HT1A receptors in cortex, hippocampus and amygdala in depression or anxiety (Akimova et al., 2009). Treatment with antidepressants leads to a reduction in raphe 5-HT1A binding potential (Gray et al., 2013), and the GG-genotype ha been 
associated with reduced response or resistance to antidepressant treatment. Taken together these results implicate dys-regulation of 5-HT1A gene transcription in predisposition to depression and related disorders, and in reducing response to antidepressant treatment.

\section{FREUD-1/FREUD-2 REPRESSION OF THE 5-HT1A PROMOTER}

Freud-1 was identified as a strong repressor of 5-HT1A autoreceptors on raphe neurons, but also represses the receptor in non-serotonergic neurons (Ou et al., 2003). Freud-1 is strongly expressed in raphe, PFC and hippocampus and colocalized with 5-HT1A receptors. Freud-1 appears to be stress-sensitive, as chronic stress in rats reduced Freud-1 levels in PFC while increasing 5-HT1A receptor levels, perhaps representing a compensatory adaptation to the stress (Iyo et al., 2009). In humans, Freud-1 and 5-HT1A protein levels were reduced in PFC of depressed subjects particular younger subjects, suggesting an early role (Szewczyk et al., 2010). While Freud-1 protein was reduced, Freud-1 is inhibited by calcium-CaMK and could downregulate 5-HT1A expression in response to reduced calcium levels $(\mathrm{Ou}$ et al., 2003). Since CaMKII is primarily expressed in pyramidal neurons, calcium-mediated inactivation of Freud-1 may be more specific to these neurons compared to interneurons, leading to calcium-mediated up-regulation of 5-HT1A heteroreceptors specifically in pyramidal neurons.

Freud-2 is a homologue of Freud-1 and binds to a site adjacent to Freud-1 to repress 5-HT1A receptor expression (Hadjighassem et al., 2009, 2011). Unlike Freud-1, Freud-2 sparsely expressed in the raphe, but is strongly expressed in PFC where it is colocalized with 5-HT1A receptors and a trend for reduced Freud-2 in the PFC of depressed patients was observed (Hadjighassem et al., 2009). Down-regulation of Freud-2 may be beneficial in depression to increase 5-HT1A expression in pyramidal neurons and enhance their firing activity.

\section{GLUCOCORTICOID-MEDIATED REPRESSION OF THE 5-HT1A PROMOTER}

The 5-HT1A receptor gene is repressed by glucocorticoids, particular in the hippocampus which expresses both high and low affinity glucorticoid receptors (MR and GR, respectively). Together the MR/GR complex represses 5-HT1A promoter at a negative GRE, as well as indirectly by suppressing Sp1-induced promoter activity (Meijer et al., 2000; Ou et al., 2001). Studies in rodents have shown that post-synaptic $5-\mathrm{HT}_{1 \mathrm{~A}}$ receptors are impacted by stress or corticosteroids. $5-\mathrm{HT}_{1 \mathrm{~A}}$ receptors in the rodent hippocampus (Chalmers et al., 1994; Lopez et al., 1998; van Riel et al., 2003, 2004) and basolateral anterior, basolateral ventral and basomedial amygdaloid nuclei as well as the hypothalamus (Vicentic et al., 2006) are desensitized or downregulated after chronic stress or corticosterone administration. In addition, socially stressed tree shrews have reduced 5-HT1A receptor levels in the posterior cingulate cortex, parietal cortex, hippocampus, and PFC. These stress-induced effects are prevented by adrenalectomy (Chalmers et al., 1994) and suggest a key role of stress in 5-HT1A receptor dys-regulation. Similarly, SSRI induced reduction in 5-HT1A autoreceptor binding is observed in chronic stress models but not naïve animals (Rainer et al., 2012). In human social anxiety, 5-HT1A receptors are reduced in amygdala and cingulate cortex and negatively correlated with plasma cortisol levels, consistent with glucocorticoid-induced down-regulation of the receptor in anxiety-associated brain regions (Lanzenberger et al., 2007, 2010).

Targeting elevated activity of the hypothalamo-pituitary axis or glucocorticoid signaling in anxiety and depression may have several beneficial effects via alteration in the serotonin system via up-regulation of 5-HT1A heteroreceptors, including a preferential effect to enhance hippocampal 5-HT1A receptors which are the most sensitive to glucocorticoids (Meijer and de Kloet, 1998). In models with chronic elevation of glucocorticoids, glucocorticoid inhibition would induce a more general up-regulation of 5-HT1A heteroreceptors throughout the brain, although the specificity for pyramidal vs. interneuron 5-HT1A receptors remain to be clarified.

\section{CONCLUSION: INTEGRATED MODEL OF 5-HT-PREFRONTAL CIRCUITRY IN ANXIETY AND DEPRESSION}

Recent and increasingly sophisticated mouse genetic models have resulted in a more precise dissection of the roles of 5-HT activity, and 5-HT1A autoreceptors vs. heteroreceptors in anxietyand depression-like behavior in rodents. These models have been examined for their anxiety and depression-like behavioral phenotypes and have shown that (see Table 1):

- Alteration in serotonin genes (5-HT1A, 5-HTT, TPH2) produces an anxiety and/or depression phenotype.

- Early post-natal modulation of the 5-HT system can produce lifelong changes in anxiety/stress reactivity.

- Both pre- and post-synaptic 5-HT1A receptors contribute to anxiety and depression phenotypes, often in opposite ways.

- High (5-HT1A autoreceptor or 5-HTT knockout) or low (TPH2 or Pet-1 knockout) 5-HT neurotransmission can result in anxiety phenotype; very low 5-HT results in anxiety and aggressive behavior.

- Downregulation of 5-HT1A autoreceptor accelerates and enhances SSRI action (Richardson-Jones et al., 2010; Bortolozzi et al., 2012).

- 5-HT1A receptors are required for neurogenic and anti-anxiety actions of chronic SSRI treatment (Santarelli et al., 2003).

In order to begin to integrate results obtained from these studies, we have proposed a model of 5-HT-PFC circuitry that takes into account the presence of 5-HT1A heteroreceptors on both interneurons and pyramidal neurons (Figures 1,2). The model of anxiety considers that early post-natal circuitry is critical, while the depression model propose the role of a different population of PFC neurons during later development. The model postulates that behavioral phenotype shifts as serotonin activity increases:

- No or very low 5-HT: depression and aggression phenotype (high risk for suicidal behavior).

- Low 5-HT: anxiety (early post-natal) and depression (adolescent-adult).

- Normal 5-HT: no anxiety, aggression, and depression.

- High 5-HT: anxiety (early post-natal) phenotype. 
Predictions of the model include the co-morbidity of anxiety and depression (at low 5-HT), alternation between depressed and anxious states (low to very low 5-HT), as well as the effectiveness of SSRI on both anxiety and depression (increasing 5-HT from very low or low to normal). Additionally, 5-HT1A-mediated inhibition of interneuronal firing is predicted to play a key role in activation of PFC pyramidal neurons that could either induce anxiety (during early post-natal period) or reduce depression in adult. The importance of this circuit in behavior remains unclear, in part because selective modulation of 5-HT1A receptors in PFC interneurons has not been achieved.

The specific role of interneuronal 5-HT1A receptors in regulating pyramidal neurons has been studied electrophysiologically, however their role in behavior has yet to be specifically addressed. An understanding of the role of both pyramidal and interneuronal 5-HT1A heteroreceptors in behavior and how their expression may change in human depression and anxiety may provide important insights into targeting distinct populations of 5-HT1A heteroreceptors by transcriptional modifiers. To date, interneuron-specific expression of CRE for conditional knockout is limited to interneuron subtype (calbindin, parvalbumin, or somatostatin), but not specific brain regions. Systemic administration of 5-HT1A agonists, such as DPAT, activates pyramidal firing preferential through the interneuronal pathway, but also inhibits 5-HT neurons via 5-HT1A autoreceptor activation (Llado-Pelfort et al., 2012). However, new generation 5-HT1A agonist show promise in targeting post-synaptic 5-HT1A receptors, and may prove selective to interneurons (Llado-Pelfort et al., 2010), and more effective as antidepressants than less selective 5-HT1A agonists such as buspirone (Rush et al., 2009). Alternately, pharmacological modification of transcription factors that show regions specific activity on 5-HT1A transcription, such as Deaf1 or MR, may provide new approaches to treat depression or augment antidepressant activity.

\section{ACKNOWLEDGMENT}

Grant support from Canadian Institutes of Health Research, Ontario Mental Health Foundation, and the Canadian Partnership for Stroke Recovery is gratefully acknowledged.

\section{REFERENCES}

aan het Rot, M., Mathew, S. J., and Charney, D. S. (2009). Neurobiological mechanisms in major depressive disorder. CMAJ 180, 305-313. doi: 10.1503/cmaj.080697

Aan Het Rot, M., Zarate, C. A. Jr., Charney, D. S., and Mathew, S. J. (2012). Ketamine for depression: where do we go from here? Biol. Psychiatry 72, 537-547. doi: 10.1016/j.biopsych.2012.05.003

Adeosun, S. O., Albert, P. R., Austin, M. C., and Iyo, A. H. (2012). 17betaestradiol-induced regulation of the novel 5-HT(1A)-related transcription factors NUDR and Freud-1 in SH SY5Y cells. Cell. Mol. Neurobiol. 32, 517-521. doi: 10.1007/s10571-012-9809-3

Akimova, E., Lanzenberger, R., and Kasper, S. (2009). The serotonin1 A receptor in anxiety disorders. Biol. Psychiatry 66, 627-635. doi: 10.1016/j.biopsych.2009.03.012

Albert, P. R. (2012). Transcriptional regulation of the 5-HT1A receptor: implications for mental illness. Philos. Trans. R. Soc. Lond. B Biol. Sci. 367, 2402-2415. doi: 10.1098/rstb.2011.0376

Albert, P. R., and Francois, B. L. (2010). Modifying 5-HT1A receptor gene expression as a new target for antidepressant therapy. Front. Neurosci. 4:35. doi: 10.3389/fnins.2010.00035
Albert, P. R., and Tiberi, M. (2001). Receptor signaling and structure: insights from serotonin-1 receptors. Trends Endocrinol. Metab. 12, 453-460. doi: 10.1016/S1043-2760(01)00498-2

Albert, P. R., Zhou, Q. Y., Van Tol, H. H., Bunzow, J. R., and Civelli, O. (1990). Cloning, functional expression, and mRNA tissue distribution of the rat 5-hydroxytryptamine1A receptor gene. J. Biol. Chem. 265, 5825-5832.

Amargos-Bosch, M., Bortolozzi, A., Puig, M. V., Serrats, J., Adell, A., Celada, P., et al. (2004). Co-expression and in vivo interaction of serotonin $1 \mathrm{~A}$ and serotonin2A receptors in pyramidal neurons of prefrontal cortex. Cereb. Cortex 14, 281-299. doi: 10.1093/cercor/bhg128

Ansorge, M. S., Zhou, M., Lira, A., Hen, R., and Gingrich, J. A. (2004). Earlylife blockade of the 5-HT transporter alters emotional behavior in adult mice. Science 306, 879-881. doi: 10.1126/science.1101678

Asberg, M. (1997). Neurotransmitters and suicidal behavior. The evidence from cerebrospinal fluid studies. Ann. N.Y. Acad. Sci. 836, 158-181.

Audero, E., Mlinar, B., Baccini, G., Skachokova, Z. K., Corradetti, R., and Gross, C. (2013). Suppression of serotonin neuron firing increases aggression in mice. J. Neurosci. 33, 8678-8688. doi: 10.1523/JNEUROSCI.206712.2013

Bang, S. J., Jensen, P., Dymecki, S. M., and Commons, K. G. (2012). Projections and interconnections of genetically defined serotonin neurons in mice. Eur. J. Neurosci. 35, 85-96. doi: 10.1111/j.1460-9568.2011.07936.x

Barnes, N. M., and Sharp, T. (1999). A review of central 5-HT receptors and their function. Neuropharmacology 38, 1083-1152. doi: 10.1016/S00283908(99)00010-6

Beique, J. C., Campbell, B., Perring, P., Hamblin, M. W., Walker, P., Mladenovic, L., et al. (2004). Serotonergic regulation of membrane potential in developing rat prefrontal cortex: coordinated expression of 5-hydroxytryptamine (5-HT)1A, 5-HT2A, and 5-HT7 receptors. J. Neurosci. 24, 4807-4817. doi: 10.1523/JNEUROSCI.5113-03.2004

Benedetti, F., Radaelli, D., Poletti, S., Locatelli, C., Dallaspezia, S., Lorenzi, C., et al. (2011). Association of the C(-1019)G 5-HT1A promoter polymorphism with exposure to stressors preceding hospitalization for bipolar depression. J. Affect. Disord. 132, 297-300. doi: 10.1016/j.jad.2011.02.024

Benekareddy, M., Goodfellow, N. M., Lambe, E. K., and Vaidya, V. A. (2010). Enhanced function of prefrontal serotonin 5-HT(2) receptors in a rat model of psychiatric vulnerability. J. Neurosci. 30, 12138-12150. doi: 10.1523/JNEUROSCI.3245-10.2010

Booij, L., Tremblay, R. E., Leyton, M., Seguin, J. R., Vitaro, F., Gravel, P., et al. (2010). Brain serotonin synthesis in adult males characterized by physical aggression during childhood: a 21-year longitudinal study. PLoS ONE 5:e11255. doi: 10.1371/journal.pone.0011255

Bortolozzi, A., Castane, A., Semakova, J., Santana, N., Alvarado, G., Cortes, R., et al. (2012). Selective siRNA-mediated suppression of 5-HT1A autoreceptors evokes strong anti-depressant-like effects. Mol. Psychiatry 17, 612-623. doi: $10.1038 / \mathrm{mp} .2011 .92$

Bouwknecht, J. A., van der Gugten, J., Groenink, L., Olivier, B., and Paylor, R. E. (2004). Effects of repeated testing in two inbred strains on flesinoxan doseresponse curves in three mouse models for anxiety. Eur. J. Pharmacol. 494, 35-44. doi: 10.1016/j.ejphar.2004.04.036

Bright, D. P., and Smart, T. G. (2013). Protein kinase C regulates tonic GABA(A) receptor-mediated inhibition in the hippocampus and thalamus. Eur. J. Neurosci. 38, 3408-3423. doi: 10.1111/ejn.12352

Cai, X., Gu, Z., Zhong, P., Ren, Y., and Yan, Z. (2002). Serotonin 5-HT1A receptors regulate AMPA receptor channels through inhibiting $\mathrm{Ca} 2+/$ calmodulindependent kinase II in prefrontal cortical pyramidal neurons. J. Biol. Chem. 277, 36553-36562. doi: 10.1074/jbc.M203752200

Caspi, A., Hariri, A. R., Holmes, A., Uher, R., and Moffitt, T. E. (2010). Genetic sensitivity to the environment: the case of the serotonin transporter gene and its implications for studying complex diseases and traits. Am. J. Psychiatry 167, 509-527. doi: 10.1176/appi.ajp.2010.09101452

Castagne, V., Porsolt, R. D., and Moser, P. (2009). Use of latency to immobility improves detection of antidepressant-like activity in the behavioral despair test in the mouse. Eur. J. Pharmacol. 616, 128-133. doi: 10.1016/j.ejphar.2009. 06.018

Celada, P., Puig, M., Amargos-Bosch, M., Adell, A., and Artigas, F. (2004). The therapeutic role of 5-HT(1A) and 5-HT(2A) receptors in depression. J. Psychiatry Neurosci. 29, 252-265. 
Chalmers, D. T., Lopez, J. F., Vazquez, D. M., Akil, H., and Watson, S. J. (1994). Regulation of hippocampal 5-HT1A receptor gene expression by dexamethasone. Neuropsychopharmacology 10, 215-222. doi: 10.1038/npp. 1994.24

Charest, A., Wainer, B. H., and Albert, P. R. (1993). Cloning and differentiationinduced expression of a murine serotonin1A receptor in a septal cell line. J. Neurosci. 13, 5164-5171.

Chen, Y. J., Zhang, M., Yin, D. M., Wen, L., Ting, A., Wang, P., et al. (2010). ErbB4 in parvalbumin-positive interneurons is critical for neuregulin 1 regulation of long-term potentiation. Proc. Natl. Acad. Sci. U.S.A. 107, 21818-21823. doi: 10.1073/pnas.1010669107

Chipman, P., Jorm, A. F., Tan, X. Y., and Easteal, S. (2010). No association between the serotonin-1A receptor gene single nucleotide polymorphism rs6295C/G and symptoms of anxiety or depression, and no interaction between the polymorphism and environmental stressors of childhood anxiety or recent stressful life events on anxiety or depression. Psychiatr. Genet. 20, 8-13. doi: 10.1097/YPG.0b013e3283351140

Crawley, J. N. (2008). Behavioral phenotyping strategies for mutant mice. Neuron 57, 809-818. doi: 10.1016/j.neuron.2008.03.001

Czesak, M., Le Francois, B., Millar, A. M., Deria, M., Daigle, M., Visvader, J. E., et al. (2012). Increased serotonin-1A (5-HT1A) autoreceptor expression and reduced raphe serotonin levels in deformed epidermal autoregulatory factor-1 (Deaf-1) gene knock-out mice. J. Biol. Chem. 287, 6615-6627. doi: 10.1074/jbc.M111.293027

Czesak, M., Lemonde, S., Peterson, E. A., Rogaeva, A., and Albert, P. R. (2006). Cell-specific repressor or enhancer activities of Deaf-1 at a serotonin 1A receptor gene polymorphism. J. Neurosci. 26, 1864-1871. doi 10.1523/JNEUROSCI.2643-05.2006

de Almeida, J., and Mengod, G. (2008). Serotonin 1A receptors in human and monkey prefrontal cortex are mainly expressed in pyramidal neurons and in a GABAergic interneuron subpopulation: implications for schizophrenia and its treatment. J. Neurochem. 107, 488-496. doi: 10.1111/j.1471-4159.2008. 05649.x

DeFelipe, J., Arellano, J. I., Gomez, A., Azmitia, E. C., and Munoz, A. (2001). Pyramidal cell axons show a local specialization for GABA and 5-HT inputs in monkey and human cerebral cortex. J. Comp. Neurol. 433, 148-155. doi: $10.1002 / \mathrm{cne} .1132$

Donaldson, Z. R., Nautiyal, K. M., Ahmari, S. E., and Hen, R. (2013). Genetic approaches for understanding the role of serotonin receptors in mood and behavior. Curr. Opin. Neurobiol. 23, 399-406. doi: 10.1016/j.conb.2013.01.011

Donaldson, Z. R., Piel, D. A., Santos, T. L., Richardson-Jones, J., Leonardo, E. D., Beck, S. G., et al. (2014). Developmental effects of serotonin 1A autoreceptors on anxiety and social behavior. Neuropsychopharmacology 39, 291-302. doi: 10.1038/npp.2013.185

Duman, R. S., and Li, N. (2012). A neurotrophic hypothesis of depression: role of synaptogenesis in the actions of NMDA receptor antagonists. Philos. Trans. R. Soc. Lond. B Biol. Sci. 367, 2475-2484. doi: 10.1098/rstb. 2011.0357

Ferres-Coy, A., Santana, N., Castane, A., Cortes, R., Carmona, M. C., Toth, M. et al. (2013). Acute 5-HT(1A) autoreceptor knockdown increases antidepressant responses and serotonin release in stressful conditions. Psychopharmacology (Berl.) 225, 61-74. doi: 10.1007/s00213-012-2795-9

Garcia-Garcia, A. L., Newman-Tancredi, A., and Leonardo, E. D. (2013). 5$\mathrm{HT}(1 \mathrm{~A})$ receptors in mood and anxiety: recent insights into autoreceptor versus heteroreceptor function. Psychopharmacology (Berl.) 231, 623-636. doi: 10.1007/s00213-013-3389-x

Goodfellow, N. M., Benekareddy, M., Vaidya, V. A., and Lambe, E. K. (2009). Layer II/III of the prefrontal cortex: inhibition by the serotonin 5-HT1A receptor in development and stress. J. Neurosci. 29, 10094-10103. doi: 10.1523/JNEUROSCI.1960-09.2009

Gorwood, P. (2004). Generalized anxiety disorder and major depressive disorder comorbidity: an example of genetic pleiotropy? Eur. Psychiatry 19, 27-33. doi: 10.1016/j.eurpsy.2003.10.002

Gray, N. A., Milak, M. S., Delorenzo, C., Ogden, R. T., Huang, Y. Y., Mann, J. J., et al. (2013). Antidepressant treatment reduces serotonin-1A autoreceptor binding in major depressive disorder. Biol. Psychiatry 74, 26-31. doi: 10.1016/j.biopsych.2012.11.012

Gross, C., and Hen, R. (2004). The developmental origins of anxiety. Nat. Rev. Neurosci. 5, 545-552. doi: 10.1038/nrn1429
Gross, C., Zhuang, X., Stark, K., Ramboz, S., Oosting, R., Kirby, L., et al. (2002). Serotonin1A receptor acts during development to establish normal anxiety-like behaviour in the adult. Nature 416, 396-400. doi: 10.1038/416396a

Hadjighassem, M. R., Austin, M. C., Szewczyk, B., Daigle, M., Stockmeier, C. A., and Albert, P. R. (2009). Human Freud-2/CC2D1B: a novel repressor of postsynaptic serotonin-1A receptor expression. Biol. Psychiatry 66, 214-222. doi: 10.1016/j.biopsych.2009.02.033

Hadjighassem, M. R., Galaraga, K., and Albert, P. R. (2011). Freud-2/CC2D1B mediates dual repression of the serotonin-1A receptor gene. Eur. J. Neurosci. 33, 214-223. doi: 10.1111/j.1460-9568.2010.07498.x

Hamani, C., and Nobrega, J. N. (2012). Preclinical studies modeling deep brain stimulation for depression. Biol. Psychiatry 72, 916-923. doi: 10.1016/j.biopsych.2012.05.024

Hedlund, P. B., Huitron-Resendiz, S., Henriksen, S. J., and Sutcliffe, J. G. (2005). 5-HT7 receptor inhibition and inactivation induce antidepressantlike behavior and sleep pattern. Biol. Psychiatry 58, 831-837. doi: 10.1016/j.biopsych.2005.05.012

Heisler, L. K., Chu, H. M., Brennan, T. J., Danao, J. A., Bajwa, P., Parsons, L. H., et al. (1998). Elevated anxiety and antidepressant-like responses in serotonin 5 HT1A receptor mutant mice. Proc. Natl. Acad. Sci. U.S.A. 95, 15049-15054. doi: 10.1073/pnas.95.25.15049

Hendricks, T. J., Fyodorov, D. V., Wegman, L. J., Lelutiu, N. B., Pehek, E. A., Yamamoto, B., et al. (2003). Pet-1 ETS gene plays a critical role in 5-HT neuron development and is required for normal anxiety-like and aggressive behavior. Neuron 37, 233-247. doi: 10.1016/S0896-6273(02)01167-4

Hesselgrave, N., and Parsey, R. V. (2013). Imaging the serotonin 1A receptor using [11C]WAY100635 in healthy controls and major depression. Philos. Trans. R. Soc. Lond. B Biol. Sci. 368:20120004. doi: 10.1098/rstb.2012.0004

Holmes, A. (2008). Genetic variation in cortico-amygdala serotonin function and risk for stress-related disease. Neurosci. Biobehav. Rev. 32, 1293-1314. doi: 10.1016/j.neubiorev.2008.03.006

Holmes, A., Murphy, D. L., and Crawley, J. N. (2002). Reduced aggression in mice lacking the serotonin transporter. Psychopharmacology (Berl.) 161, 160-167. doi: 10.1007/s00213-002-1024-3

Holmes, A., Murphy, D. L., and Crawley, J. N. (2003). Abnormal behavioral phenotypes of serotonin transporter knockout mice: parallels with human anxiety and depression. Biol. Psychiatry 54, 953-959. doi: 10.1016/j.biopsych.2003. 09.003

Holtzheimer, P. E., and Mayberg, H. S. (2011). Deep brain stimulation for psychiatric disorders. Annu. Rev. Neurosci. 34, 289-307. doi: 10.1146/annurev-neuro061010-113638

Iyo, A. H., Kieran, N., Chandran, A., Albert, P. R., Wicks, I., Bissette, G., et al. (2009). Differential regulation of the serotonin 1 A transcriptional modulators five prime repressor element under dual repression-1 and nuclear-deformed epidermal autoregulatory factor by chronic stress. Neuroscience 163, 1119-1127. doi: 10.1016/j.neuroscience.2009.07.053

Jacobsen, J. P., Medvedev, I. O., and Caron, M. G. (2012a). The 5-HT deficiency theory of depression: perspectives from a naturalistic 5-HT deficiency model, the tryptophan hydroxylase $2 \mathrm{Arg} 439$ His knockin mouse. Philos. Trans. R. Soc. Lond. B Biol. Sci. 367, 2444-2459. doi: 10.1098/rstb.2012.0109

Jacobsen, J. P., Siesser, W. B., Sachs, B. D., Peterson, S., Cools, M. J., Setola, V., et al. (2012b). Deficient serotonin neurotransmission and depression-like serotonin biomarker alterations in tryptophan hydroxylase 2 (Tph2) loss-of-function mice. Mol. Psychiatry 17, 694-704. doi: 10.1038/mp.2011.50

Jacobsen, K. X., Vanderluit, J., Slack, R. S., and Albert, P. R. (2008). HES1 regulates 5-HT1A receptor gene transcription at a functional polymorphism: essential role in developmental expression. Mol. Cell. Neurosci. 38, 349-358. doi: 10.1016/j.mcn.2008.03.007

Jans, L. A., Riedel, W. J., Markus, C. R., and Blokland, A. (2007). Serotonergic vulnerability and depression: assumptions, experimental evidence and implications. Mol. Psychiatry 12, 522-543. doi: 10.1038/sj.mp. 4001920

Jennings, K. A., Loder, M. K., Sheward, W. J., Pei, Q., Deacon, R. M., Benson, M. A. et al. (2006). Increased expression of the 5-HT transporter confers a low-anxiety phenotype linked to decreased 5-HT transmission. J. Neurosci. 26, 8955-8964. doi: 10.1523/JNEUROSCI.5356-05.2006

Kalueff, A. V., Gallagher, P. S., and Murphy, D. L. (2006). Are serotonin transporter knockout mice 'depressed'?: hypoactivity but no anhedonia. Neuroreport 17, 1347-1351. doi: 10.1097/01.wnr.0000230514.08962.76 
Karg, K., Burmeister, M., Shedden, K., and Sen, S. (2011). The serotonin transporter promoter variant (5-HTTLPR), stress, and depression meta-analysis revisited: evidence of genetic moderation. Arch. Gen. Psychiatry 68, 444-454. doi: 10.1001/archgenpsychiatry.2010.189

Kim, J. C., Cook, M. N., Carey, M. R., Shen, C., Regehr, W. G., and Dymecki, S. M. (2009). Linking genetically defined neurons to behavior through a broadly applicable silencing allele. Neuron 63, 305-315. doi: 10.1016/j.neuron.2009.07.010

Kishi, T., Yoshimura, R., Fukuo, Y., Okochi, T., Matsunaga, S., Umene-Nakano, W., et al. (2013). The serotonin 1A receptor gene confer susceptibility to mood disorders: results from an extended meta-analysis of patients with major depression and bipolar disorder. Eur. Arch. Psychiatry Clin. Neurosci. 263, 105-118. doi: 10.1007/s00406-012-0337-4

Kocsis, B., Varga, V., Dahan, L., and Sik, A. (2006). Serotonergic neuron diversity: identification of raphe neurons with discharges time-locked to the hippocampal theta rhythm. Proc. Natl. Acad. Sci. U.S.A. 103, 1059-1064. doi: 10.1073/pnas.0508360103

Krishnan, V., Graham, A., Mazei-Robison, M. S., Lagace, D. C., Kim, K. S., Birnbaum, S., et al. (2008). Calcium-sensitive adenylyl cyclases in depression and anxiety: behavioral and biochemical consequences of isoform targeting. Biol. Psychiatry 64, 336-343. doi: 10.1016/j.biopsych.2008.03.026

Krishnan, V., and Nestler, E. J. (2008). The molecular neurobiology of depression. Nature 455, 894-902. doi: 10.1038/nature07455

Kushwaha, N., and Albert, P. R. (2005). Coupling of 5-HT1A autoreceptors to inhibition of mitogen-activated protein kinase activation via Gbetagamma subunit signaling. Eur. J. Neurosci. 21, 721-732. doi: 10.1111/j.1460-9568.2005. 03904.x

Kusserow, H., Davies, B., Hortnagl, H., Voigt, I., Stroh, T., Bert, B., et al. (2004). Reduced anxiety-related behaviour in transgenic mice overexpressing serotonin 1A receptors. Brain Res. Mol. Brain Res. 129, 104-116. doi: 10.1016/j.molbrainres.2004.06.028

Lanfumey, L., Mongeau, R., Cohen-Salmon, C., and Hamon, M. (2008). Corticosteroid-serotonin interactions in the neurobiological mechanisms of stress-related disorders. Neurosci. Biobehav. Rev. 32, 1174-1184. doi: 10.1016/j.neubiorev.2008.04.006

Lanzenberger, R., Wadsak, W., Spindelegger, C., Mitterhauser, M., Akimova, E., Mien, L. K., et al. (2010). Cortisol plasma levels in social anxiety disorder patients correlate with serotonin-1A receptor binding in limbic brain regions. Int. J. Neuropsychopharmacol. 13, 1129-1143. doi: 10.1017/S146114571 0000581

Lanzenberger, R. R., Mitterhauser, M., Spindelegger, C., Wadsak, W., Klein, N., Mien, L. K., et al. (2007). Reduced serotonin-1A receptor binding in social anxiety disorder. Biol. Psychiatry 61, 1081-1089. doi: 10.1016/j.biopsych.2006.05.022

Lebe, M., Hasenbring, M. I., Schmieder, K., Jetschke, K., Harders, A., Epplen, J. T., et al. (2013). Association of serotonin-1A and $-2 \mathrm{~A}$ receptor promoter polymorphisms with depressive symptoms, functional recovery, and pain in patients 6 months after lumbar disc surgery. Pain 154, 377-384. doi: 10.1016/j.pain.2012.11.017

Le François, B., Czesak, M., Steubl, D., and Albert, P. R. (2008). Transcriptional regulation at a HTR1A polymorphism associated with mental illness. Neuropharmacology 55, 977-985. doi: 10.1016/j.neuropharm.2008. 06.046

Lembo, P. M., and Albert, P. R. (1995). Multiple phosphorylation sites are required for pathway-selective uncoupling of the 5-hydroxytryptamine1A receptor by protein kinase C. Mol. Pharmacol. 48, 1024-1029.

Lemonde, S., Turecki, G., Bakish, D., Du, L., Hrdina, P. D., Bown, C. D., et al. (2003). Impaired repression at a 5-hydroxytryptamine 1A receptor gene polymorphism associated with major depression and suicide. J. Neurosci. 23, 8788-8799.

Lenicov, F. R., Lemonde, S., Czesak, M., Mosher, T. M., and Albert, P. R. (2007). Cell-type specific induction of tryptophan hydroxylase-2 transcription by calcium mobilization. J. Neurochem. 103, 2047-2057. doi: 10.1111/j.14714159.2007.04903.x

Lesch, K. P., Araragi, N., Waider, J., van den Hove, D., and Gutknecht, L. (2012). Targeting brain serotonin synthesis: insights into neurodevelopmental disorders with long-term outcomes related to negative emotionality, aggression and antisocial behaviour. Philos. Trans. R. Soc. Lond. B Biol. Sci. 367, 2426-2443. doi: 10.1098/rstb.2012.0039
Lira, A., Zhou, M., Castanon, N., Ansorge, M. S., Gordon, J. A., Francis, J. H., et al. (2003). Altered depression-related behaviors and functional changes in the dorsal raphe nucleus of serotonin transporter-deficient mice. Biol. Psychiatry 54, 960-971. doi: 10.1016/S0006-3223(03)00696-6

Lister, R. G. (1987). The use of a plus-maze to measure anxiety in the mouse. Psychopharmacology (Berl.) 92, 180-185. doi: 10.1007/BF00177912

Liu, C., Maejima, T., Wyler, S. C., Casadesus, G., Herlitze, S., and Deneris, E. S. (2010). Pet-1 is required across different stages of life to regulate serotonergic function. Nat. Neurosci. 13, 1190-1198. doi: 10.1038/nn.2623

Liu, X., and Gershenfeld, H. K. (2003). An exploratory factor analysis of the Tail Suspension Test in 12 inbred strains of mice and an F2 intercross. Brain Res. Bull. 60, 223-231. doi: 10.1016/S0361-9230(03)00033-9

Llado-Pelfort, L., Assie, M. B., Newman-Tancredi, A., Artigas, F., and Celada, P. (2010). Preferential in vivo action of F15599, a novel 5-HT(1A) receptor agonist, at postsynaptic 5-HT(1A) receptors. Br. J. Pharmacol. 160, 1929-1940. doi: 10.1111/j.1476-5381.2010.00738.x

Llado-Pelfort, L., Santana, N., Ghisi, V., Artigas, F., and Celada, P. (2012). 5-HT1A receptor agonists enhance pyramidal cell firing in prefrontal cortex through a preferential action on GABA interneurons. Cereb. Cortex 22, 1487-1497. doi: $10.1093 /$ cercor/bhr220

Lopez, J. F., Chalmers, D. T., Little, K. Y., and Watson, S. J. (1998). A.E. Bennett Research Award. Regulation of serotonin1A, glucocorticoid, and mineralocorticoid receptor in rat and human hippocampus: implications for the neurobiology of depression. Biol. Psychiatry 43, 547-573. doi: 10.1016/S00063223(97)00484-8

Lucas, G., Rymar, V. V., Du, J., Mnie-Filali, O., Bisgaard, C., Manta, S., et al. (2007). Serotonin(4) (5-HT(4)) receptor agonists are putative antidepressants with a rapid onset of action. Neuron 55, 712-725. doi: 10.1016/j.neuron.2007.07.041

Mann, J. J. (2013). The serotonergic system in mood disorders and suicidal behaviour. Philos. Trans. R. Soc. Lond. B Biol. Sci. 368, 20120537. doi: 10.1098/rstb.2012.0537

Meijer, O. C., and de Kloet, E. R. (1998). Corticosterone and serotonergic neurotransmission in the hippocampus: functional implications of central corticosteroid receptor diversity. Crit. Rev. Neurobiol. 12, 1-20. doi: 10.1615/CritRevNeurobiol.v12.i1-2.10

Meijer, O. C., Williamson, A., Dallman, M. F., and Pearce, D. (2000). Transcriptional repression of the 5-HT1A receptor promoter by corticosterone via mineralocorticoid receptors depends on the cellular context. J. Neuroendocrinol. 12, 245-254. doi: 10.1046/j.1365-2826.2000.00445.x

Mekli, K., Payton, A., Miyajima, F., Platt, H., Thomas, E., Downey, D., et al. (2011). The HTR1A and HTR1B receptor genes influence stressrelated information processing. Eur. Neuropsychopharmacol. 21, 129-139. doi: 10.1016/j.euroneuro.2010.06.013

Meltzer, H. Y., Massey, B. W., and Horiguchi, M. (2012). Serotonin receptors as targets for drugs useful to treat psychosis and cognitive impairment in schizophrenia. Curr. Pharm. Biotechnol. 13, 1572-1586. doi: 10.2174/138920112800 784880

Millan, M. J. (2004). The role of monoamines in the actions of established and "novel" antidepressant agents: a critical review. Eur. J. Pharmacol. 500, 371-384. doi: 10.1016/j.ejphar.2004.07.038

Mogha, A., Guariglia, S. R., Debata, P. R., Wen, G. Y., and Banerjee, P. (2012). Serotonin 1A receptor-mediated signaling through ERK and PKCalpha is essential for normal synaptogenesis in neonatal mouse hippocampus. Transl. Psychiatry 2, e66. doi: 10.1038/tp.2011.58

Molina, E., Cervilla, J., Rivera, M., Torres, F., Bellon, J. A., Moreno, B., et al. (2011). Polymorphic variation at the serotonin 1-A receptor gene is associated with comorbid depression and generalized anxiety. Psychiatr. Genet. 21, 195-201. doi: 10.1097/YPG.0b013e3283457a48

Mosienko, V., Bert, B., Beis, D., Matthes, S., Fink, H., Bader, M., et al. (2012). Exaggerated aggression and decreased anxiety in mice deficient in brain serotonin. Transl. Psychiatry 2, e122. doi: 10.1038/tp.2012.44

Newman-Tancredi, A., and Albert, P. R. (2012). "Gene polymorphism at serotonin 5-HT1A receptors: moving towards personalized medicine for psychosis and mood deficits," in Schizophrenia Research: Recent Advances, ed T. Sumiyoshi (New York, NY: Nova Publishers), 337-358.

Ordureau, A., Enesa, K., Nanda, S., Le Francois, B., Peggie, M., Prescott, A., et al. (2013). DEAF1 is a Pellinol-interacting protein required for interferon production by Sendai virus and double stranded RNA. J. Biol. Chem. 288, 24569-24580. doi: 10.1074/jbc.M113.479550 
Ou, X. M., Lemonde, S., Jafar-Nejad, H., Bown, C. D., Goto, A., Rogaeva, A., et al. (2003). Freud-1, A novel calcium-regulated repressor of the 5-HT1A receptor gene. J. Neurosci. 23, 7415-7425.

Ou, X. M., Storring, J. M., Kushwaha, N., and Albert, P. R. (2001). Heterodimerization of mineralocorticoid and glucocorticoid receptors at a novel negative response element of the 5-HT1A receptor gene. J. Biol. Chem. 276, 14299-14307. doi: 10.1074/jbc.M005363200

Palchaudhuri, M., and Flugge, G. (2005). 5-HT1A receptor expression in pyramidal neurons of cortical and limbic brain regions. Cell Tissue Res. 321, 159-172. doi: 10.1007/s00441-005-1112-x

Parks, C. L., Robinson, P. S., Sibille, E., Shenk, T., and Toth, M. (1998). Increased anxiety of mice lacking the serotonin1A receptor. Proc. Natl. Acad. Sci. U.S.A. 95, 10734-10739. doi: 10.1073/pnas.95.18.10734

Piszczek, L., Schlax, K., Wyrzykowska, A., Piszczek, A., Audero, E., and Thilo Gross, C. (2013). Serotonin 1A auto-receptors are not sufficient to modulate anxiety in mice. Eur. J. Neurosci. 38, 2621-2627. doi: 10.1111/ejn.12260

Porsolt, R. D., Le Pichon, M., and Jalfre, M. (1977). Depression: a new animal model sensitive to antidepressant treatments. Nature 266, 730-732. doi: $10.1038 / 266730 \mathrm{a} 0$

Puig, M. V., and Gulledge, A. T. (2011). Serotonin and prefrontal cortex function: neurons, networks, and circuits. Mol. Neurobiol. 44, 449-464. doi: $10.1007 / \mathrm{s} 12035-011-8214-0$

Rainer, Q., Nguyen, H. T., Quesseveur, G., Gardier, A. M., David, D. J., and Guiard, B. P. (2012). Functional status of somatodendritic serotonin 1A autoreceptor after long-term treatment with fluoxetine in a mouse model of anxiety/depression based on repeated corticosterone administration. Mol. Pharmacol. 81, 106-112. doi: 10.1124/mol.111.075796

Rajkowska, G., Miguel-Hidalgo, J. J., Dubey, P., Stockmeier, C. A., and Krishnan, K. R. (2005). Prominent reduction in pyramidal neurons density in the orbitofrontal cortex of elderly depressed patients. Biol. Psychiatry 58, 297-306. doi: 10.1016/j.biopsych.2005.04.013

Rajkowska, G., O’Dwyer, G., Teleki, Z., Stockmeier, C. A., and Miguel-Hidalgo, J. J. (2007). GABAergic neurons immunoreactive for calcium binding proteins are reduced in the prefrontal cortex in major depression. Neuropsychopharmacology 32, 471-482. doi: 10.1038/sj.npp.1301234

Ramboz, S., Oosting, R., Amara, D. A., Kung, H. F., Blier, P., Mendelsohn, M., et al. (1998). Serotonin receptor 1A knockout: an animal model of anxiety-related disorder. Proc. Natl. Acad. Sci. U.S.A. 95, 14476-14481. doi: 10.1073/pnas.95.24.14476

Ressler, K. J., and Mayberg, H. S. (2007). Targeting abnormal neural circuits in mood and anxiety disorders: from the laboratory to the clinic. Nat. Neurosci. 10, 1116-1124. doi: 10.1038/nn1944

Richardson-Jones, J. W., Craige, C. P., Guiard, B. P., Stephen, A., Metzger, K. L., Kung, H. F., et al. (2010). 5-HT(1A) Autoreceptor levels determine vulnerability to stress and response to antidepressants. Neuron 65, 40-52. doi: 10.1016/j.neuron.2009.12.003

Richardson-Jones, J. W., Craige, C. P., Nguyen, T. H., Kung, H. F., Gardier, A. M., Dranovsky, A., et al. (2011). Serotonin-1A autoreceptors are necessary and sufficient for the normal formation of circuits underlying innate anxiety. J. Neurosci. 31, 6008-6018. doi: 10.1523/JNEUROSCI.5836-10.2011

Rush, A. J., Warden, D., Wisniewski, S. R., Fava, M., Trivedi, M. H., Gaynes, B. N., et al. (2009). STAR*D: revising conventional wisdom. CNS Drugs 23, 627-647. doi: 10.2165/00023210-200923080-00001

Sachs, B. D., Jacobsen, J. P., Thomas, T. L., Siesser, W. B., Roberts, W. L., and Caron, M. G. (2013). The effects of congenital brain serotonin deficiency on responses to chronic fluoxetine. Transl. Psychiatry 3:e291. doi: 10.1038/tp. 2013.65

Santana, N., Bortolozzi, A., Serrats, J., Mengod, G., and Artigas, F. (2004). Expression of serotonin $1 \mathrm{~A}$ and serotonin $2 \mathrm{~A}$ receptors in pyramidal and GABAergic neurons of the rat prefrontal cortex. Cereb. Cortex 14, 1100-1109. doi: 10.1093/cercor/bhh070

Santarelli, L., Saxe, M., Gross, C., Surget, A., Battaglia, F., Dulawa, S., et al. (2003). Requirement of hippocampal neurogenesis for the behavioral effects of antidepressants. Science 301, 805-809. doi: 10.1126/science. 1083328

Sarkar, A., Chachra, P., and Vaidya, V. A. (2013). Postnatal FluoxetineEvoked Anxiety Is Prevented by Concomitant 5-HT Receptor Blockade and Mimicked by Postnatal 5-HT Receptor Stimulation. Biol. Psychiatry. doi: 10.1016/j.biopsych.2013.11.005
Saudou, F., Amara, D. A., Dierich, A., LeMeur, M., Ramboz, S., Segu, L., et al. (1994). Enhanced aggressive behavior in mice lacking 5-HT1B receptor. Science 265, 1875-1878. doi: 10.1126/science.8091214

Savitz, J., Lucki, I., and Drevets, W. C. (2009). 5-HT(1A) receptor function in major depressive disorder. Prog. Neurobiol. 88, 17-31. doi: 10.1016/j.pneurobio.2009.01.009

Szewczyk, B., Albert, P. R., Burns, A. M., Czesak, M., Overholser, J. C., Jurjus, G. J., et al. (2009). Gender-specific decrease in NUDR and 5-HT1A receptor proteins in the prefrontal cortex of subjects with major depressive disorder. Int. J. Neuropsychopharmacol. 12, 155-168. doi: 10.1017/S1461145708009012

Szewczyk, B., Albert, P. R., Rogaeva, A., Fitzgibbon, H., May, W. L., Rajkowska, G., et al. (2010). Decreased expression of Freud-1/CC2D1A, a transcriptional repressor of the 5-HT1receptor, A, in the prefrontal cortex of subjects with major depression. Int. J. Neuropsychopharmacol. 13, 1089-1101. doi: $10.1017 / \mathrm{S} 1461145710000301$

Tanaka, K. F., Ahmari, S. E., Leonardo, E. D., Richardson-Jones, J. W., Budreck, E. C., Scheiffele, P., et al. (2010). Flexible Accelerated STOP Tetracycline Operatorknockin (FAST): a versatile and efficient new gene modulating system. Biol. Psychiatry 67, 770-773. doi: 10.1016/j.biopsych.2009.12.020

Trivedi, M. H., Rush, A. J., Wisniewski, S. R., Nierenberg, A. A., Warden, D., Ritz, L., et al. (2006). Evaluation of outcomes with citalopram for depression using measurement-based care in $\mathrm{STAR}^{\star} \mathrm{D}$ : implications for clinical practice. Am. J. Psychiatry 163, 28-40. doi: 10.1176/appi.ajp.163.1.28

van Riel, E., Meijer, O. C., Steenbergen, P. J., and Joels, M. (2003). Chronic unpredictable stress causes attenuation of serotonin responses in cornu ammonis 1 pyramidal neurons. Neuroscience 120, 649-658. doi: 10.1016/S03064522(03)00355-5

van Riel, E., van Gemert, N. G., Meijer, O. C., and Joels, M. (2004). Effect of early life stress on serotonin responses in the hippocampus of young adult rats. Synapse 53, 11-19. doi: 10.1002/syn.20033

Varga, V., Losonczy, A., Zemelman, B. V., Borhegyi, Z., Nyiri, G., Domonkos, A., et al. (2009). Fast synaptic subcortical control of hippocampal circuits. Science 326, 449-453. doi: 10.1126/science. 1178307

Veenstra-Vanderweele, J., Muller, C. L., Iwamoto, H., Sauer, J. E., Owens, W. A., Shah, C. R., et al. (2012). Autism gene variant causes hyperserotonemia, serotonin receptor hypersensitivity, social impairment and repetitive behavior. Proc. Natl. Acad. Sci. U.S.A. 109, 5469-5474. doi: 10.1073/pnas.1112345109

Vicentic, A., Francis, D., Moffett, M., Lakatos, A., Rogge, G., Hubert, G. W., et al. (2006). Maternal separation alters serotonergic transporter densities and serotonergic $1 \mathrm{~A}$ receptors in rat brain. Neuroscience 140, 355-365. doi: 10.1016/j.neuroscience.2006.02.008

Walther, D. J., Peter, J. U., Bashammakh, S., Hortnagl, H., Voits, M., Fink, H., et al. (2003). Synthesis of serotonin by a second tryptophan hydroxylase isoform. Science 299, 76. doi: 10.1126/science. 1078197

Warden, M. R., Selimbeyoglu, A., Mirzabekov, J. J., Lo, M., Thompson, K. R., Kim, S. Y., et al. (2012). A prefrontal cortex-brainstem neuronal projection that controls response to behavioural challenge. Nature 492, 428-432.

Wasserman, D., Geijer, T., Sokolowski, M., Rozanov, V., and Wasserman, J. (2006). The serotonin 1A receptor $\mathrm{C}(-1019) \mathrm{G}$ polymorphism in relation to suicide attempt. Behav. Brain Funct. 2, 14. doi: 10.1186/1744-9081-2-14

Weisstaub, N. V., Zhou, M., Lira, A., Lambe, E., Gonzalez-Maeso, J., Hornung, J. P., et al. (2006). Cortical 5-HT2A receptor signaling modulates anxiety-like behaviors in mice. Science 313, 536-540. doi: 10.1126/science.1123432

Whiteford, H. A., Degenhardt, L., Rehm, J., Baxter, A. J., Ferrari, A. J., Erskine, H. E., et al. (2013). Global burden of disease attributable to mental and substance use disorders: findings from the Global Burden of Disease Study (2010). Lancet 382, 1575-1586. doi: 10.1016/S0140-6736(13)61611-6

Wong, D. T., Perry, K. W., and Bymaster, F. P. (2005). Case history: the discovery of fluoxetine hydrochloride (Prozac). Nat. Rev. Drug Discov. 4, 764-774.

Wu, X., Kushwaha, N., Albert, P. R., and Penington, N. J. (2002). A critical protein kinase C phosphorylation site on the 5-HT(1A) receptor controlling coupling to N-type calcium channels. J. Physiol. 538, 41-51. doi: 10.1113/jphysiol.2001.012668

Xu, B., Zang, K., Ruff, N. L., Zhang, Y. A., McConnell, S. K., Stryker, M. P., et al. (2000). Cortical degeneration in the absence of neurotrophin signaling: dendritic retraction and neuronal loss after removal of the receptor TrkB. Neuron 26, 233-245. doi: 10.1016/S0896-6273(00)81153-8

Yip, L., Su, L., Sheng, D., Chang, P., Atkinson, M., Czesak, M., et al. (2009). Deaf1 isoforms control the expression of genes encoding peripheral tissue antigens 
in the pancreatic lymph nodes during type 1 diabetes. Nat. Immunol. 10, 1026-1033. doi: 10.1038/ni.1773

Young, S. N., and Leyton, M. (2002). The role of serotonin in human mood and social interaction. Insight from altered tryptophan levels. Pharmacol. Biochem. Behav. 71, 857-865. doi: 10.1016/S0091-3057(01)00670-0

Yuen, E. Y., Jiang, Q., Chen, P., Feng, J., and Yan, Z. (2008). Activation of 5HT2A/C receptors counteracts 5-HT1A regulation of n-methyl-D-aspartate receptor channels in pyramidal neurons of prefrontal cortex. J. Biol. Chem. 283, 17194-17204. doi: 10.1074/jbc.M801713200

Conflict of Interest Statement: The authors declare that the research was conducted in the absence of any commercial or financial relationships that could be construed as a potential conflict of interest.
Received: 17 March 2014; accepted: 16 May 2014; published online: 06 June 2014. Citation: Albert PR, Vahid-Ansari F and Luckhart C (2014) Serotonin-prefrontal cortical circuitry in anxiety and depression phenotypes: pivotal role of pre-and postsynaptic 5-HT1A receptor expression. Front. Behav. Neurosci. 8:199. doi: 10.3389/ fnbeh.2014.00199

This article was submitted to the journal Frontiers in Behavioral Neuroscience.

Copyright (C) 2014 Albert, Vahid-Ansari and Luckhart. This is an open-access article distributed under the terms of the Creative Commons Attribution License (CC BY). The use, distribution or reproduction in other forums is permitted, provided the original author(s) or licensor are credited and that the original publication in this journal is cited, in accordance with accepted academic practice. No use, distribution or reproduction is permitted which does not comply with these terms. 